\title{
THE CRITICAL ANALYSIS OF SCENARIO CONSTRUCTION IN THE POLISH FORESIGHT INITIATIVES
}

\author{
Joanicjusz NAZARKO, Anna KONONIUK \\ Faculty of Management, Bialystok University of Technology, \\ Wiejska str. 45A, PL 15-351 Bialystok, Poland
}

Received 22 December 2012; accepted 19 May 2013

\begin{abstract}
The aim of the article is to present the diagnosis of scenario method application in the Polish foresight initiatives. The concept of scenario method, its evolution, the state of the art of the Polish foresight studies and the critical analysis of the application of this method have been presented. From the questionnaire results the authors have identified (i) the approach used in scenario construction, (ii) the most important phases of scenario construction, (iii) the interconnection of scenario method with other methods of scenario construction, (iv) the profile of experts involved in foresight projects, (v) the profile of experts involved in scenario construction, (vi) the application of the triangulation principle in scenario construction, (vii) the application of wild cards in scenario construction and techniques to identify them, (viii) the average time of scenario construction process, (ix) the linkage of scenarios to other documents, (x) the number of scenarios elaborated upon, and (xi) the main difficulties in the process of scenario construction. To achieve article aims there have been used the following research methods: a literature review, the method of critical analysis and logical construction, survey research, the status of Polish foresight projects, interim and final report analysis. The research has been funded by the National Science Centre in Poland within a research project entitled Scenarios in future shaping and anticipation for foresight studies, project number: 4194/B/H03/2011/40.
\end{abstract}

Keywords: foresight, future anticipation, scenario method, triangulation, wild cards.

Reference to this paper should be made as follows: Nazarko, J.; Kononiuk, A. 2013. The critical analysis of scenario construction in the Polish foresight initiatives, Technological and Economic Development of Economy 19(3): 510-532.

JEL Classification: E27, O21, O22, O31, O32.

Corresponding author Joanicjusz Nazarko

E-mail: j.nazarko@pb.edu.pl 


\section{Introduction}

According to Giddens, one of the most important features of the contemporary society is its attitude to time, particularly to the future, which anticipation should be well-thought-of and in the ideal situation carefully planned (Tsoukas, Shepherd 2004). This thesis seems to gain its importance in times characterized by the high dynamics of social, economic, technological, political and legal factors which influence the processing of information coming from a great variety of sources. As noted by Zavadskas and Turskis (2010), in many real-world decision problems, a decision-maker has a set of multiple conflicting objectives. Traditional forecasting methods - being fixed in their assumptions - often fail to predict the future in turbulent times. A policy tool that takes into perspective the widely understood environment is foresight defined as systemic, participatory, future intelligence gathering and medium to long term vision building process aimed at present day decisions and mobilizing joint actions (Georghiou et al. 2008). It should be emphasized that the complexity and essence of foresight makes it not only a useful tool of future anticipation, but also an element of its shaping and even managing. The uniqueness of foresight is its additive value, which is a desired future vision. The creation of desired visions is possible due to the implementation of the scenario method in foresight research process. As noted by Bradfield et al. (2005) scenarios may be treated as forums to involve multiple agencies and stakeholders in policy decisions, enabling joined-up analysis and creating an accommodation platform to assist policy implementation. Nevertheless, the majority of the existing published works focuses on the adaptation of the scenario method to strategic management in enterprises, taking no account of its meaning in foresight studies funded by public institutions. (Gierszewska, Romanowska 2009; Heijden 1996; Ringland 1998; Lindgren, Banhold 2003; Heijden et al. 2002; Perechuda, Sobińska 2008; O’Keefe, Wright 2010). To the authors' knowledge, the problem of critical analysis of scenario method construction in foresight studies has not been touched upon. The aim of this article is to fill this knowledge gap.

\section{The concept of scenario method}

In the process of the scenario method's evolution, there have been posited many definitions and possible approaches to and techniques of scenario construction. Although the method is perceived as the basic one of future studies, the notion of a scenario is increasingly misused and abused (Godet, Roubelaut 1996) and as noted by Khakee gives rise to confusion (Bradfield et al. 2005). The objective of this paper is to begin to address this confusion by tracing the different methodologies of scenario construction in the Polish foresight studies.

According to Ringland (1998) scenarios are the part of strategic planning that relates to the tools and techniques of uncertainty management. At the same time, Ringland emphasises that scenarios should not be equal to forecast understood as the description of reality projection or the vision, and indicates that forecast is only a single picture of reality. Ringland's perception of the scenario method seems to correspond with that of other futures scholars such as Schwartz, van der Heidjen and Schutte (Van der Heidjen, Schutte 2000), and Sarpong who state that the essence of the scenario method is not knowing about the future, but rather preparing for it (Sarpong 2011). The authors of this article also share this view. 
Van der Heijden enlists five features of well written scenarios, namely: linking historical and present events with hypothetical events in the future, carrying storylines that can be expressed in simple diagrams, plausibility, reflecting pre-determined elements, and identifying signposts or indicators that a given story is occurring (Saritas, Nugroho 2012).

For the benefit of foresight studies, the authors of this article modify the definition of the scenario method proposed by Jasiński (1999) who perceives scenario method as a description of logical and coherent course of events with the aim of presenting how the current state of reality transforms into a new one. A scenario is a description of factors' interdependence determining the development of the given situation in time. The interdependence between factors could be so minutely described that the simulation of the given situation is possible.

The authors posit the complementary to Jasiński's definition of scenario method, perceiving it as the logical and formal construction of an alternative vision of the desired future based on the involvement of heterogeneous experts' groups taking into account the detailed study and understanding of factors shaping researched phenomenon and enabling the making of reasonable decisions about the future.

The emphasis on the heterogeneity of experts stems from the authors' studies of minimum quality criteria for the scenarios introduced by Stewart (2008). The first criterion concerns the change in the perception of the world by the people involved in scenario construction. This criterion seems to be parallel to Wack's postulate, according to whom the most important aim of the scenario method is challenging decision makers' assumptions about the world's functioning, and at the same time convincing them to change their perception of reality, which may even result in revolutionary transformation.

The second criterion is based on Ashby's Law of Requisite Variety and states that the scenario method is useful only when it is based on the diversity of worldviews (Stewart 2008). The authors of the article state that minimum quality criteria posited by Stewart seem to be indispensable to understanding the scenario method, and therefore the authors posit their application for foresight studies.

At the same time, the authors of the article posit that heterogeneity of the experts may be enhanced by the triangulation concept, which involves looking at the same phenomenon or research question-from more than one source of data (Decrop 1999). It could also be perceived as an assessment of the research phenomena form different points of view with the aim of better understanding its variety (Stake 2009).

\section{The evolution of scenario method}

According to the authors of the article, in the last decade, the development of the scenario method was significantly enhanced by the publications of authors such as van Notten et al. (2003), Aligica (2005), Bradfield et al. (2005), Borjeson et al. (2006), Hiltunen (2006), Zurek and Heinrichs (2007), Bishop et al. (2007), Stewart (2008), Saritas and Nugroho (2012) and van Vliet et al. (2012).

The works of van Notten et al. (2003) and Borjeson et al. (2006) were devoted to the typology and classification of scenarios. Bradfield et al. (2005) carried out comparative analysis of the three schools of scenario construction, namely the school of intuitive logic that of prob- 
abilistic modified trends school and La Prospective. The work of Hiltunen (2006) primarily focused on the relation between weak signals, cards and scenarios. Aligicia (2005) described the role of epistemological element in scenario construction aiming at the complexity and uncertainty reduction, knowledge increase and new knowledge creation presenting at the same time - arguments for those researchers who question the scientific character of the scenario method. The work of Zurek and Heinrich (2007) is devoted to the presentation of possible ways of linking scenarios across geographical scales in international environmental assessment. The authors differentiate between five ways of possible linking, namely: equivalent, consistent, coherent, comparable and complementary. The aim of the work of Bishop et al. (2007) was the presentation of possible scenario techniques. The authors demonstrated the usefulness and strong and weak sides of 23 techniques grouped into eight categories. The work of Stewart (2008) is devoted to the presentation of the experience of Australian futurologists on the new approach to scenario construction based on integrated theories, especially Wilber's AQAL (All Quandrant, All Level, All Lines, All States, All Types) metatheory. Saritas and Nugroho (2012) combine systemic foresight, network analysis and scenario methods to propose an 'Evolutionary Scenario Approach', which explains the ways in which the future may unfold, based on the mapping of the gradual change and the dynamics of aspects or variables that characterise a series of circumstances in a period of time. Results of the work by van Vliet et al. (2012) show that the use of structuring tools can have a negative effect on the creativity of the workshop, but the influence seems to vary between the different tools. The problem of using scenarios for future anticipation is still present in the leading journals on technological change (Cairns et al. 2013).

\section{Polish foresight studies}

Until 2012, in Poland more than forty national, regional and sectoral foresight projects were carried out. The first steps of foresight in Poland were taken in year 2003-2005 by the Ministry of Science and Informatization, which carried out the Pilot Foresight Program in the field of Health and Life. An important landmark in Polish foresight history was the National Foresight Program "Poland 2020" (carried out from February 2006 to March 2009). To implement project's results, the Ministry of Science and Higher Education launched the third national foresight project entitled "National Foresight Programme - the results' implementation".

Besides national projects, in Poland there have been taken the following projects of sectoral, regional and thematic type, namely (Kononiuk 2013):

- eighteen completed regional and sectoral foresight projects granted financial support from the Sectoral Operational Programme "Improvement of the Competitiveness of Enterprises" (Priority 1: "Enhancement of a knowledge-based economy and the business environment", Measure 1.4: "Strengthening of co-operation between the R\&D sphere and the economy", Submeasure 1.4.5: "Research and applied projects in the area of monitoring and foresight of technology development";

- twenty two regional and sectoral foresight projects which were granted the financial support from the EU Operational Program "Innovative Economy 2007-2013" 
(Priority 1: "Research and development of new technologies", Measure 1.1: "Support for scientific research for the building of knowledge based economy", Submeasure 1.1.1: "Research projects with the use of foresight method";

- two thematic foresight projects, i.e. on human capital in modern economy and technological foresight of Polish industry - Insight 2030 as well as two regional foresight projects carried out in the West Pomeranian and Lublin Voivodships.

The thematic area of the Polish foresight initiatives focuses on the issue of setting the vision of development of both traditional branches such as founding, copper, lignite, coal extraction industry, and forestry, as well as the modern sectors such as metallic, ceramic and composite materials, cosmic technologies, or nanotechnologies.

For the time being, the most updated state of the art of Polish foresight studies may be found in the expertise commissioned by the Ministry of Science and Higher Education entitled Evaluation research of the Polish Foresight Projects, carried out by the researchers from the Bialystok University of Technology (Nazarko 2012). Other existing published works on Polish foresight projects mainly comprise interim and final reports on projects' results as well as publications presenting methods or research process applied in foresight initiatives and attempts of evaluation of foresight activities. The publications concerning methodological issues focus on demonstrating the research procedures in foresight projects (Nazarko, Ejdys 2011), the role of the scenario method in future anticipation (Kononiuk 2010), the role of roadmapping process in foresight studies (Sacio-Szymańska et al. 2010), the importance of unprecedented events (i.e. weak signals or wild cards) in future management (Kononiuk 2009) and weak signals in risk management (Magruk 2009), the innovative classification of foresight research methods (Magruk 2011), the role of knowledge and technology mapping (Gudanowska 2011) and the application of structural analysis for the classification of factors influencing regional nanotechnology development (Nazarko et al. 2011) to name but a few. The attempts of evaluation concern foresight projects of all types. The assessment of the Polish National Foresight Program "Poland 2020" may be found in publications of the Ministry of Science and Higher Education (Ministry of Science and Higher Education 2009), the publications of the Forecasts Committee "Poland 2000 PLUS" (Kleer, Wierzbicki 2009), the expertise of Central Mining Institute (Central Mining Institute 2007) and publications on the role of Delphi method in the National Foresight Program "Poland 2020" (Kowalewska, Gluszczyński 2009) and the role of the Support Group comprising young scientists in the same foresight exercise (Kononiuk et al. 2009). The evaluation of regional and sectoral foresight initiatives may be found in publications by Glińska et al. (2008), Rogut and Piasecki (2011), Nazarko (2012), Nazarko et al. (2013).

\section{The critical analysis of scenario construction in Polish foresight regional and sectoral initiatives}

The source of data for the critical analysis of scenario construction in Polish foresight regional and sectoral initiatives are: questionnaires addressed to sectoral foresight project coordinators; the unpublished $\mathrm{PhD}$ thesis by Kononiuk (2010) on scenario method application in foresight studies; content analysis of projects' final and interim reports as well as projects' web pages. 
Research for this paper has been carried out in three phases. The first phase was the identification of all completed foresight projects, in which the scenario method has been applied. The source of data for this phase was the $\mathrm{PhD}$ thesis by Kononiuk. The authors have identified eighteen foresight projects which were granted the financial support from the Sectoral Operational Programme "Improvement of the Competitiveness of Enterprises" (Priority 1: "Enhancement of a knowledge-based economy and the business environment", Measure 1.4: "Strengthening of co-operation between the R\&D sphere and the economy", Submeasure 1.4.5: "Research and applied projects in the area of monitoring and foresight of technology development"). The second phase was the collection of data from the projects' coordinators through questionnaires. The aim of the third part was to derive the missing data, which was done on the basis of content analysis of projects' final and interim reports as well as projects' web pages.

The names of foresight projects of regional and sectoral type have been presented in Tables 1 and 2.

The questionnaires were completed by seventeen of eighteen respondents. The respondents of MEDT project refused to take part in the research. Nevertheless, the authors of the article gained the information about their method of scenario construction on the basis of final report (Wójcicki, Ładyżyński 2008).

For the purpose of this publication, the authors would like to present projects' coordinators' answers to the following research questions:

1. What approach has been used to scenario construction?

2. What are the most important phases of scenario construction?

3. What is the interconnection of scenario method with other methods of scenario construction?

4. What is the profile of experts involved in foresight projects?

5. What is the profile of experts involved in scenario construction?

6. Has the selection of experts been supported by triangulation?

7. Have the wild cards been taken into account? What kind of technique has been applied in the process of their identification?

8. What is the average time of scenario construction process?

9. Is there a linkage of scenarios to other documents?

10. How many scenarios have been elaborated?

11. What are the main difficulties in the process of scenario construction?

\subsection{Adopted approach}

The first research problem concerned the approach applied to scenario construction. In particular, the authors of the study were interested in whether or not the scenario construction processes in Polish regional and sectoral foresight initiatives were supported by experts working in panels, cross-impact analysis, or morphological analysis. The aforementioned three approaches have been described by Ringland (1998). On the basis of completed questionnaire analysis in all cases, expert approach was used. Executors of projects such as FEI, PV, MCCM, MAV, PM, CE, SLV reported that they had additionally used cross-impact analysis. 
Table 1. List of sectoral foresight projects in which scenario method has been applied

\begin{tabular}{cll}
\hline $\begin{array}{c}\text { Project } \\
\text { number }\end{array}$ & \multicolumn{1}{c}{ Project name } & \multicolumn{1}{c}{ Sector } \\
\hline 1 & Technological foresight of Polish founding (PF) & founding \\
\hline 2 & Technological foresight in the area of polymer materials (PM) & polymer materials \\
\hline 3 & $\begin{array}{l}\text { Technological development scenarios of the lignite extraction } \\
\text { and processing industry (LE) }\end{array}$ & lignite extraction \\
\hline 4 & $\begin{array}{l}\text { Technological development scenarios of the coal extraction } \\
\text { industry (CE) }\end{array}$ & coal extraction \\
\hline 5 & $\begin{array}{l}\text { Development scenarios of metallic, ceramic and composite } \\
\text { material technologies (MCCM) }\end{array}$ & $\begin{array}{l}\text { metallic, ceramic and } \\
\text { composite materials }\end{array}$ \\
\hline 6 & $\begin{array}{l}\text { Assessment of the perspectives and benefits from the } \\
\text { utilisation of satellite and cosmic technologies development in } \\
\text { Poland (SCT) }\end{array}$ & $\begin{array}{l}\text { cosmic technologies } \\
\text { of aviation cluster „Aviation Valley” (AV) }\end{array}$ \\
\hline 8 & $\begin{array}{l}\text { Technological development scenarios of copper and accompanying } \\
\text { raw materials extraction industry in Poland (CO) }\end{array}$ & copper \\
\hline 9 & $\begin{array}{l}\text { Monitoring system and development scenarios of medical } \\
\text { technologies in Poland (MEDT) }\end{array}$ & medical technologies \\
\hline 10 & $\begin{array}{l}\text { Technological development scenarios of the fuel and energy } \\
\text { complex for the country's energetic security (FEI) }\end{array}$ & $\begin{array}{l}\text { fuel and energy } \\
\text { industry }\end{array}$ \\
\hline
\end{tabular}

Table 2. List of the regional foresight projects in which scenario method has been applied

\begin{tabular}{cl}
\hline $\begin{array}{c}\text { Project } \\
\text { number }\end{array}$ & \multicolumn{1}{c}{ Project name } \\
\hline 1 & Key Technologies for the sustainable development of slaskie voivodship (SLV) \\
\hline 2 & Technological foresight for the sustainable developement of Malopolska (MPV) \\
\hline 3 & $\begin{array}{l}\text { Monitoring and forecasting of key, innovative technologies for the sustainable } \\
\text { development of mazowieckie voivodship (MZV) }\end{array}$ \\
\hline 4 & Loris Vision. Regional technological foresight (lodzkie voivodship) (LOV) \\
\hline 5 & Opolskie voivodship as the region of sustainable development region al foresight 2020 (OPV) \\
\hline 6 & Key technologies for the sustainable development of swietokrzyskie voivodship (SWV) \\
\hline 8 & Key technologies for the sustainable development of podkarpackie voivodship (PKV) \\
\hline
\end{tabular}

\subsection{The key phases of scenario construction and the interconnection of scenario method with other methods}

The key issue of the authors' interest was getting to know the way of scenario construction in projects under analysis. On the basis of answers analysis, it may be concluded that the process of scenario construction within projects varies significantly. The key phases of scenario construction indicated by respondents are presented in Table 3. 
Table 3.The key phases of scenario construction in the Polish foresight projects of regional and sectoral type

\begin{tabular}{|c|c|}
\hline $\begin{array}{c}\text { Project } \\
\text { abbreviation }\end{array}$ & $\begin{array}{l}\text { The key phases of scenario construction/The way of scenario building in the } \\
\text { projects }\end{array}$ \\
\hline $\mathrm{PF}$ & Trade consultations with the application of the Delphi method. \\
\hline PM & $\begin{array}{l}\text { 1. Identifying the variants of environment behaviour. } 2 \text {. Setting the vision of } \\
\text { technological development. } 3 \text {. Assessing the probability of vision occurrence in } \\
\text { each variant. }\end{array}$ \\
\hline LE & $\begin{array}{l}\text { 1. Simulation modelling. 2. Adaptive optimisation. 3. Variants prioritisation with } \\
\text { the use of brainstorming. }\end{array}$ \\
\hline $\mathrm{CE}$ & $\begin{array}{l}\text { 1. A current state diagnosis. 2. Setting the existed and forecasted external } \\
\text { conditions. 3. Description of innovativeness and prioritisation of the existing } \\
\text { technologies. } 4 \text {. Scenarios construction of detailed technologies. 5. Scenarios } \\
\text { verification. } 6 \text {. The construction of complex scenario of coal extraction industry. }\end{array}$ \\
\hline MCCM & 1. Identifying the key factors. 2. SWOT analysis. 3. Cross-impact analysis. \\
\hline SCT & 1. Trend analysis. 2. Identifying the key factors. 3. Scenario building. \\
\hline AV & Discussion panels. \\
\hline $\mathrm{CO}$ & $\begin{array}{l}\text { 1. Analysis of raw materials balance, forecasts and marginal conditions. 2. The } \\
\text { assessment of technology innovativeness in the sector. 3. Key technologies } \\
\text { identification } 4 \text {. Delphi study in two rounds. }\end{array}$ \\
\hline FEI & $\begin{array}{l}\text { 1. Identifying the variants of environment behaviour. } 2 \text {. Setting the vision of } \\
\text { technological development. } 3 \text {. Assessing the probability of vision occurrence in } \\
\text { each variant. }\end{array}$ \\
\hline SLV & $\begin{array}{l}\text { 1. The procedure of linking visions to scenario variants. } 2 \text {. The development } \\
\text { of a given technology in the communal/industrial/transport/telecommunication } \\
\text { area. 3. Preparing scenario description for the research areas. } 4 \text {. The formulation } \\
\text { of general theses. 5. Construction of optimistic, pessimistic scenario and a } \\
\text { technology roadmap. }\end{array}$ \\
\hline MPV & $\begin{array}{l}\text { 1. Diagnosis of the research area. 2. The organisation of the expert panels. } \\
\text { 3. Collecting opinions and remarks of the panelists. }\end{array}$ \\
\hline LOV & $\begin{array}{l}\text { 1. Identification of future development alternatives of voivodship. } \\
\text { 2. The selection of scenario leading to the sustainable development of voivodship. } \\
\text { 3. Offering recommendations timing at the increase of regional innovative policy } \\
\text { effectiveness. } 4 \text {. The identification of activities leading to priority technologies } \\
\text { development. }\end{array}$ \\
\hline OPV & $\begin{array}{l}\text { 1. Identifying the success factors for each research area. } 2 \text {. Construction of } \\
\text { optimistic, pessimistic and business as usual scenario for chemistry sector. }\end{array}$ \\
\hline SWV & no data available. \\
\hline PKV & $\begin{array}{l}\text { Scenarios were constructed by experts during expert workshops using cross-impact } \\
\text { analysis. }\end{array}$ \\
\hline DSV & $\begin{array}{l}\text { Scenarios were constructed by experts who were asked to present their own } \\
\text { proposals of scenarios. Then, their proposals were assessed during seminars by } \\
\text { business entrepreneurs as well as local and central administration representatives. }\end{array}$ \\
\hline
\end{tabular}

Source: authors' own study.

Scenario building phases have been distinguished in sixteen out of seventeen analysed cases, that is, with the exclusion of SWV respondents. The analysis of the data on scenario building phases in Table 3 shows that the data has been presented at different levels of detail. 
In some cases, phase descriptions seemed to be limited to scenario building methods, i.e. in PF, AV, PKV and DSV with the respondents claiming that the scenarios had been built in the scope of workshops (AV, PKV, DSV) or by trade consultations (PF). In other cases, scenario building phases have been presented at a high degree of generality (OPV) and constituted project methodology characterization rather than the actual scenario building phases (RM, MPV, LOV). In PM, SLV, FEI, the respondents described actions taken after scenario building, that is: marking out the environment behaviour variants, formulating a technological development vision, and determining the probability of the vision coming to life for given variants. In two cases, i.e. SWZ and MZV, the respondents were unable to name scenario building phases. More detailed scenario building phases were only indicated by LE, CE, SCT and MCCM respondents.

That being so, the authors have asked the respondents to send detailed reports on scenario building work in individual projects or publications on the subject matter from projects of that type. Source materials were obtained from fifteen out of eighteen analyzed projects, with the exclusion of PF, PM and LE.

On the basis of the scenario building phases analysis, four prominent scenario building forms can be distinguished: optimization modeling, scenario building based on key factors' behavior description, scenario building based on Delphi method results, and scenario building based on scenario workshops results.

LE and CE executors have applied optimization modeling. In LE, scenario building came down to simulation modeling. By contrast, scenario building in CE was based on (Dubiński, Turek 2008):

- a current state diagnosis in the scope of hard bituminous coal technology, collecting statistical data in the quantitative form;

- an introduction of trend-describing data choice algorithm, its extrapolation for developed future visions;

- formulating a list of possible future events which will influence trend lines;

- a correction of trend lines made on the basis of expert-identified event occurrence probability assessment.

A scenario structure based on key factors analysis has been applied in SCT, OPV, MCCM, PM, FEI, SLV and MEDT. At the same time, in SCT, relations among factors were not determined and the execution of the scenario method came down to building three possible scenarios of space activity financing in Poland. The work resulted in Scenario "Zero", Scenario "Poland as a member of ESA" and Scenario "Poland as a member of ESA with a complimentary national programme". In OPV project, scenario building was achieved through identification of causative success factors for each research area, and its result was the building of an optimistic, a pessimistic and a business-as-usual scenario for chemistry trade. The attempt to determine relations among factors in chosen research areas was made in MCCM, PM, FEI, SLV and MEDT. The most formalized scenario building process, complemented by the implementation of key technologies and the results of the Delphi survey, can be distinguished in PM, FEI and SLV executed in cooperation with Central Mining Institute in Katowice. The process has been presented in Figure 1. 


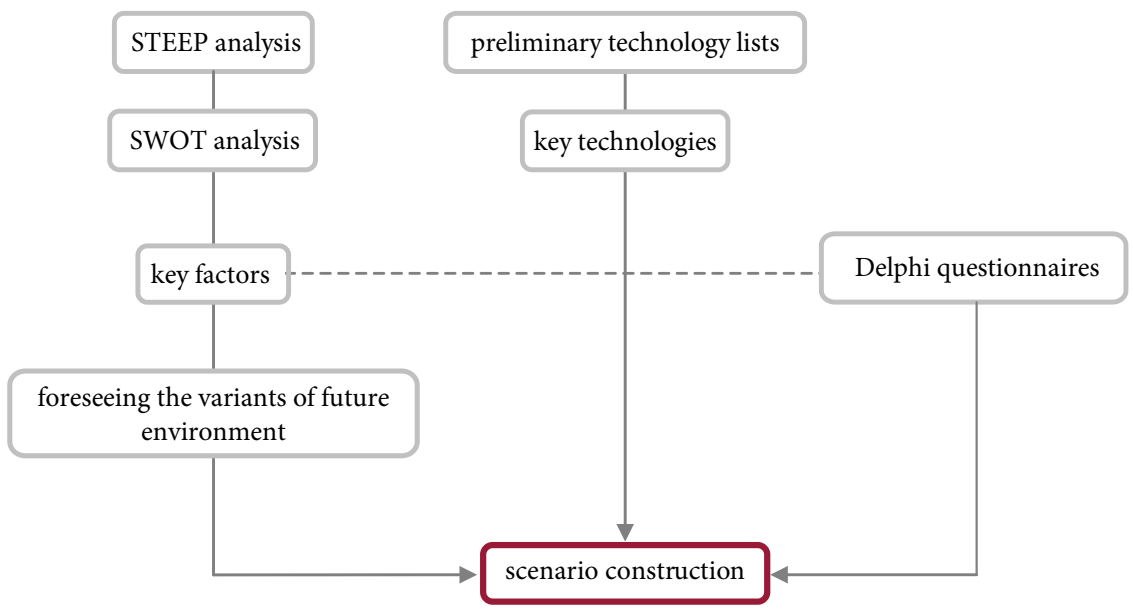

Fig. 1. Scenario building process in PM, SLV and FEI projects Source: Authors' own study on the basis of among others Czaplicka-Kolarz (2007).

The presented diagram illustrates the fact that three elements had direct influence on the scenario building, i.e. foreseeing variants of future environment behavior, a list of key technologies, and Delphi survey results. Furthermore, in Figure 1 the relation between key factors and Delphi survey has been marked, with the relation being highlighted in SLV. The authors obtained the scenarios in their final forms from FEI and SLV. The scenario method results were constituted by building of an optimistic, a realistic and a pessimistic scenario for FEI (Czaplicka-Kolarz 2007) and an optimistic, a realistic, a stagnation and a pessimistic scenario for SLV in the scope of defined research areas. Key factors in the aforementioned scenarios were distinguished on the grounds of their mutual relations analysis with the use of the MIC-MAC computer programme. In the case of PM, the respondents refused to present detailed reports on the course of scenario building. Methodology similar to the one used in PM, SLV and FEI was used in MEDT as well. Seven following phases can be discerned in that methodology (Wójcicki, Ładyżyski, 2008):

1. Identification of success and uncertainty factors which determine the future of medical technologies sector in Poland by 2020 based on SWOT analysis results and considering current sector condition analysis results as well as STEEP analysis.

2. Establishing main scenario topics on the basis of assumed behaviour on the part of factor pairs, which have the most significant influence on technology success and the greatest uncertainty in three condition categories: socio-economic, scientific-technological and business.

3. Consolidation of corresponding success and uncertainty factors in all three condition categories, leading to four sets of collective scenario assumptions.

4. Establishing the behaviour of key variables distinguished in cross-impact analysis in a way that allows for assumptions on individual scenarios to be fulfilled, and therefore enabling prerequisites of their execution to be realized. 
5. Building four scenarios in a descriptive form (including two variants of a random scenario).

6. Forming a future vision of key technologies for each of the built scenarios, in each panel's subject area and its generalization for the whole medical technologies field.

7. Instituting technological implementation areas in industry, medicine and health service.

The Delphi survey had a direct influence on scenario building in LOV, MPV (Hausner 2008), RM (Drzewiecki et al. 2008) and MZV (Szewczyk 2008). While analysing research reports, the authors have noted that in those studies, the product of scenario method was highlighted more than the implementation mechanism of the Delphi method results into the scenarios. In LOV, success scenarios method was used which consisted in choosing the scenario leading to the voivodeship's sustainable development among alternatives of the voivodeship's future development. As a result of LOV project work, Development scenarios of a voivodeship as a knowledge-based region and Scenarios of regional industries transformation have been created (Rogut, Piasecki 2008). On the other hand, as a result of a Delphi survey used in CO scenario, the following scenarios were discerned: a moderate and a sustainable development scenario, an accelerated development scenario, and - the most costly, but also highly expected - dynamic development scenario (Drzewiecki et al. 2008). The outcome of MPV project work was generating an optimistic scenario, a pessimistic scenario and a business-as-usual scenario for the following research areas: economic growth, infrastructure, natural resources and new materials (Hausner 2008). The effect of MZV project work was building neutral, negative and positive scenarios (Szewczyk 2008). In those scenarios the following elements were distinguished: economic growth, infrastructure development and spatial development, human capital, science development, political circumstances, sociological changes and changes in the natural environment (Szewczyk 2008).

Scenario building on the basis of workshops and panel discussions can be observed in four projects: PF, DSV, PKV and OPV. Attributing a key role to discussion panels in scenario building, with the exception of PF and DSV (see Table 3), can also be noted in PKV and AV. In PKV, the scenario was built through an environment factors analysis and integration of fictional factors (devised by teams of two experts) with the most probable, optimistic and pessimistic scenarios (Methodology of work execution in Priority Technologies for Sustainable Development of the Podkarpackie Voivodship project, no pagination. (Source material sent by PKV respondents). In a detailed analysis of AV project work, the authors have noticed that the final scenario formulated within the project that is Aviation industry development scenario amounted to one scenario of foresighted environment changes and was preceded by three scenarios, i.e. Scenarios: possible directions of development strategy for research and development infrastructure. The detailed scenarios built within AV are the following (Material Technologies Development Directions for "Dolina Lotnicza" Aviation Cluster. Sector foresight. Project execution final report):

- Organizing a team of research laboratories working for aviation industry.

- Research and development based on the best and geographically closest academic-research units.

- Research centers working for individual companies' centers of excellence. 
The scenarios put forward have been developed without explicit probability degrees; instead, they constituted visions, in which advantages and disadvantages were distinguished.

Based on the analysis of scenario building forms in Polish regional and trade foresight projects, the article authors have attempted to determine the extent to which the presented scenario building forms correspond to foresight research nature. Scenario building derived from optimization modeling harmonizes with the concept of probabilistic trend modification school, which, in spite of many strong points manifested in the option of assistance of mathematical probabilistic computer models and generating alternative future visions in the form of scenarios which are developed as a result of fusing assumed future events with expert assessment (Dubiński, Turek 2008) hampers broad social participation and interaction, which is a foresight research principle. The three remaining leading scenario building forms seem to correlate better to foresight research principles, mainly because of distinguishing the so-called key factors, engaging a wide circle of experts owing to the Delphi method and proposing interactions within scenario workshops. In the article authors' opinion, scenario building in MCCM, PM, FEI, SLV and MEDT were the closest to the intuitive logic school concept due to key factors defining and establishing their mutual relations. Nevertheless, the authors have noted that the final forms of scenarios are optimistic, pessimistic and neutral, which - according to practitioners in the field of scenario method in foresight research such as Miles, Ringland and Ravetz (2007) - can encourage governing bodies to choose a business-as-usual variant, the neutral one, and thus substantially reduce the significance of constructed alternative future state concepts. Exceptions to this tendency were only the scenarios within LOV and AV.

\subsection{Expert structure in foresight projects}

Even more important than the number of experts engaged in the project seems the expert structure that indicates a consensus among many social groups when it comes to future visions. On account of that, the authors of this publication have questioned the respondents about the structure of the experts engaged in the project and the scenario building. By the structure of experts the authors mean the number of academics, businesspeople, politicians and civil servants, media members, non-governmental organizations, students actively committed to project work. Eight out of seventeen executors of analysed projects were able to provide a detailed expert structure at the project level, namely DSV, CO, PF, OPV, SLV, MCCM, AV and SWV. The structure is presented in Figure 2.

On the basis of the data depicted in Figure 2 it can be noted that the most diverse expert structure was applied in three projects, DS, MCCM and SWV. In the case of DSV and MCCM, four expert groups were on the expert teams: academics, businesspeople, politicians and civil servants, who accounted for 55\%, 18\%, 18\% and 9\% respectively in DSV and $84.5 \%$, 9.5\%, 3\% and 2\% in MCCM. The structure of SWV was based on expert groups different than in DSV and MCCM; to be exact, apart from academics, businesspeople, politicians and civil servants, amounting to $48 \%, 28 \%$ and $20 \%$ respectively, there was also "other" category amounting to $4 \%$. In OPV and SLV the respondents named three expert groups, i.e. academics, businesspeople, politicians and civil servants, who constituted $55.5 \%, 20 \%$ 


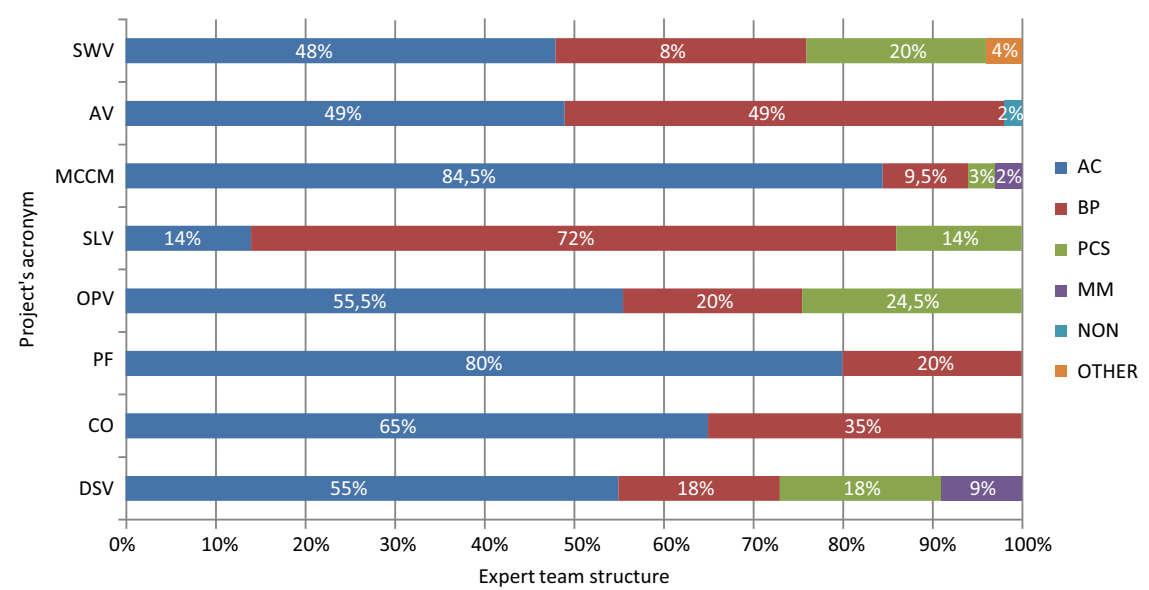

Legend: AC - academics, BP - businesspeople, PCS - politicians, civil servants, MM - media members, NON - non-governmental organizations, $\mathrm{S}$ - students, I - other (independent experts)

Fig. 2. Expert structure in chosen regional and trade foresight projects

and $24.5 \%$ respectively in OPV and $14 \%, 72 \%$ and $14 \%$ in SLV. In AV, there were also three groups on the expert team; apart from academics and businesspeople, non-governmental organizations were invited. These groups' shares in the expert team reached $49 \%, 49 \%$ and $2 \%$ respectively. In the remaining two projects, the respondents named only two expert groups, that is academics and businesspeople, who constituted 65\% and 35\% respectively of the expert team in CO and $80 \%$ and $20 \%$ in PF. In six out of eight analysed cases, i.e. in DSV, CO, PF, OPV, MCCM and SWV, definitely the most numerous group was academics, whose share equaled from 55\% for DS to $84.5 \%$ for MCCM. An exception to this tendency was the expert structure in SLV, where clearly the largest group was businesspeople at $72 \%$; the percentage of other expert groups, namely academics and non-governmental organizations with civil servants, amounted to $14 \%$ for both of the above groups. In the remaining projects, PM, LOV, FEI and MPV, academics vastly outnumbered other expert groups. The respondents from SCT, MZV, LE and CE were unable to present an expert structure. However, in the case of SCT, three expert groups were declared (academics, businesspeople and politicians with civil servants) and in the case of $\mathrm{CE}$, the respondents claimed that "many expert groups" partook in the research.

\subsection{The profile of experts involved in scenario construction}

The results presented in the previous subsection that concern the structure of experts involved in analysed foresight projects suggest that the reached consensus on development visions for the researched areas is quite often not based on agreement among many social groups. The situation is similar when it comes to experts participating in the scenario method whose point - according to foresight research idea - is to formulate desired development visions 


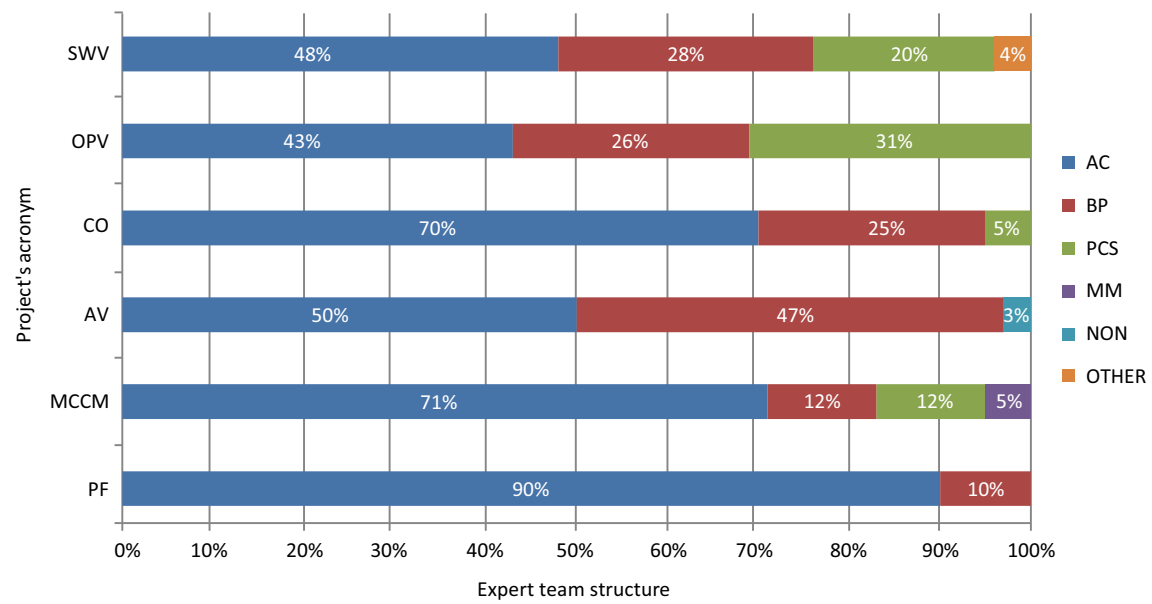

Fig. 3. Expert team structure engaged in scenario building Source: own work based on questionnaire results

devised by many stakeholders. The expert team structure engaged in building scenarios was presented by respondents from only six projects: PF, MCCM, AV, CO, OPV and SWV. The structure has been presented in Figure 3.

The most diverse structure of experts involved in scenario building was a feature of MCCM and SWV, whose expert teams each consisted of four expert groups. In MCCM, the expert structure was made of academics, businesspeople, civil servants and media members, whose share in the expert structure accounted for $71 \%, 12 \%, 12 \%$ and $5 \%$ respectively. The expert groups responsible for scenario building in SWV consisted of academics, businesspeople, politicians with civil servants and experts from the "other" category. The percentages of the groups mentioned above in the expert structure were $48 \%, 28 \%, 20 \%$ and $4 \%$ respectively.

Representatives of three circles were engaged in scenario building within CO and OPV, namely: academics, mining industry representatives and mining bureau representatives at $70 \%, 25 \%$ and $5 \%$ respectively in CO and academics, businesspeople, politicians and civil servants at $43 \%, 26 \%$ and $31 \%$ in OPV. Three expert groups participating in scenario development can be also identified in AV: academics, businesspeople and non-governmental organizations at $50 \%, 47 \%$ and $3 \%$.

In PF only two expert groups have been recognized: academics, whose share was $90 \%$ and industry representatives, who made up $10 \%$ of the team. On the grounds of these facts, the authors question the consensus among many social groups on future visions which, after all, should be the paradigm of such type of research. In spite of the obstacles presented above in defining the scenario method expert structure observed in most researched foresight initiatives, sixteen out of seventeen project executors declared that the choice of experts for the scenario method was intentional. Only CO project executors gave a negative answer to the question about choice intentionality. 


\subsection{The application of triangulation principle in scenario construction}

The questions about the structure of experts working on the project and within the scenario method, and the question about the intentionality of expert choice, as intended by the authors, were at the same time test questions about utilizing the triangulation principle ${ }^{1}$. The authors have assumed that if there is little variety in the expert structure or distinct dominance of one expert group, the triangulation principle is most likely not applied. Meanwhile, the results of triangulation principle application stand in contrast to the authors' assumptions. The application of the triangulation principle was declared by the executors of thirteen projects: MCCM, PM, SLV, LE, PF, FEI, MPV, OPV, SWV, AV and CE claimed to have applied three triangulation rules, namely the data triangulation rule, the investigator triangulation rule and the theoretical triangulation rule. The executors of DS asserted to have applied the investigator triangulation rule and the theoretical triangulation partially; the executors of PKV claimed to have applied the theoretical triangulation rule; the executors of SCT declared the application of the investigator triangulation rule. The executors of MZV and CO gave a negative answer to the question about the application of the triangulation principle, while LO executors did not answer this question. The results of the research on the triangulation principle application seem to stand in contrast to the results of the research on the expert structure. In the authors' opinion, the executors' having applied all three triangulation rules is questionable, especially in the cases where the respondents were unable to name expert structures, i.e. in LE and CE; or in the situation where the expert structure was not very diverse, i.e. in PF, OPV and MCCM; or when there was significant dominance of one expert group, namely academics, seen in the majority of researched projects, i.e. DSV, CO, PF, OPV, MCCM, PM, LOV, FEI and MPV, or businesspeople in SLV.

\subsection{The application of wild cards into scenario construction and techniques of their identification}

The next issue that intrigued the article's authors was the fact that the executors of the regional and sector foresight projects considered unprecedented events in scenario building. Those events - of high impact and low probability of occurrence - allow for alternative future conditions to be considered, broadening the extent of occurrence perception. Employing unprecedented events in scenario building in Polish regional and sector foresight projects was dealt with in seven initiatives: MZV, MCCM, FEI, CE, PM, PKV, and SCT. Based on questionnaire analysis and telephone in-depth interviews conducted with the executors of MZV and CE, the authors have established that the unprecedented events were identified with the use of the brainstorming technique. Specific unprecedented events were reported by two executors, namely MZV and CE. In the case of MZV, the 2012 UEFA European Football Championship, commonly referred to as Euro 2012, was recognized as an unprecedented event, while in CE it was discussed whether it is feasible to develop an effective energy production technology in the process of controlled thermonuclear fusion. In the remaining instances, the authors of the article were unable to obtain information on discussed unpre-

${ }^{1}$ The notion of triangulation has been described in the legend to the questionnaire. 
cedented events. This failure might be explained by certain confidentiality of the research. On the other hand, refraining from analysing unprecedented events might result from the lack of widely available analysis tools or from unfamiliarity of relations between unprecedented events and scenario building stages.

\subsection{The average time of scenario construction process}

The authors of the article have also enquired about the amount of time Polish regional and sector foresight projects executors devote to scenario building. The results have been collated in Figure 4.

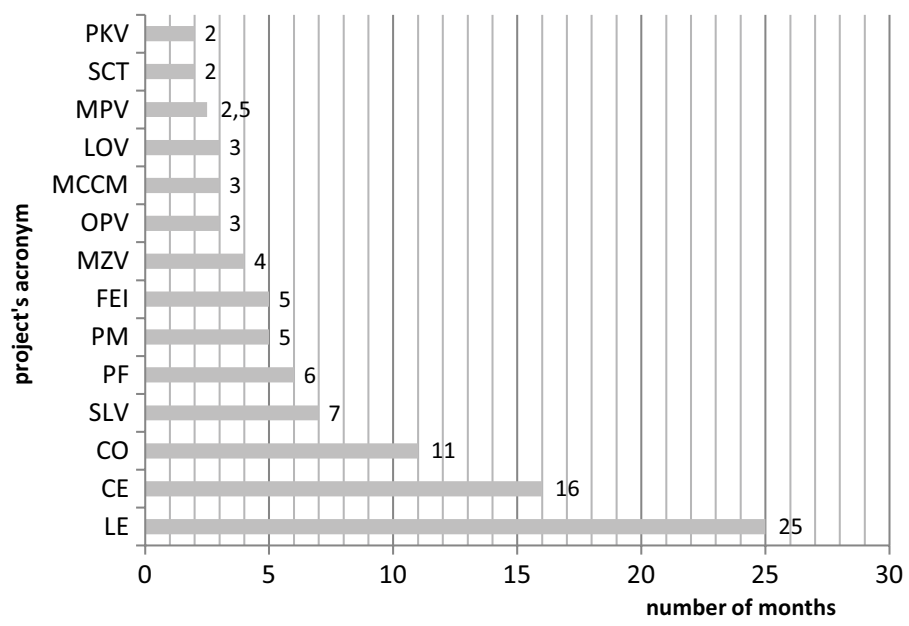

Fig. 4. Time devoted to scenario method employment in Polish regional and sector foresight projects Source: own work based on questionnaire results

The amount of time devoted to scenario method employment was declared by sixteen out of seventeen respondents. The figure above does not include data on total scenario building time in DSV and AV. For DSV, this fact results from ambiguity in determining the total scenario building time by the respondents; the answers offered were "from three months up to two years". For AV, the total scenario building time was estimated at a hundred hours, which is difficult to express on a monthly scale. Meanwhile, SWV respondents were incapable of reporting the total scenario building time. In Figure 4, one can see that the most time was devoted to scenario building within LE, namely 25 months. Also CE, CO and SLV had a long scenario building time, amounting to 16,11 and 7 months respectively. In the remaining projects, the scenario building time did not surpass six months each; the shortest time devoted to scenario building was a feature of SCT and PKV. The data presented in Figure 4 indicates that scenario building times are generally shorter than in corresponding research worldwide (according to Miles et al. 2007), the average time dedicated to foresight research scenario building equalling six months. The situation described above might be the outcome of ascribing a lesser importance to the scenario method in creating a vision of a researched area. 


\subsection{The linkage of scenarios to other documents}

The authors' next goal was to examine whether the scenario method in Polish regional and sector foresight projects is applied solely on the basis of expert knowledge generated during project execution, or the scenario method can be linked to other documents which contain scenarios or documents of strategic nature.

In thirteen out of seventeen analysed cases there were references to other documents. Specific documents were revealed by several respondents, namely CE, PF, CO, FEI, LE and MCCM. In the majority of analysed projects, apart from MCCM, experts referred to documents directly linked to the researched area. The largest amount of documents of that type was reported by CE respondents, who, among others, mentioned the following documents:

1. Scenarios of Fuel-Energy Complex Technologies Development for the Country's Energy Safety Guarantee;

2. The Strategy for Hard Bituminous Coal Mining in Poland 2007-2015;

3. Policy on Polish Power by 2030;

4. National Strategic Reference Framework 2007-2013 with Operational Programmes;

5. Regional Operational Programme for the Slaskie Voivodship 2007-2013.

In other cases, respondents reported documents such as: Scenarios for German founding (PF), Mining Industry of the Future, USA 2002, Developement of the Minerals Cycle and the Need for Minerals, UK 2001 (CO), Policy on Polish Power by 2025, National Development Plan 2007-2013 (FEI). In LE, the respondents did not mention specific documents; they only indicated that they referred to previous concepts for prospective deposit development. MCCM executors consulted other foresight projects executed in Poland and abroad, while in the scope of DSV, reputable prognoses (Japanese, American and European ones) were taken into account as far as scientific and technological development, and innovative strategies for chosen UE regions were concerned. Two projects that did not refer to other documents were PKV and AV. In PKV, it was assumed that it would be executed on the grounds of information gathered during its execution, so answers are not suggested. The objective of the main expert panel in that project was to select generated content and to evaluate it for the sake of creating the final report. In the case of $\mathrm{AV}$, the executors did not disclose the reasons for not having referred to other documents. In the cases of LOV and SWV, the author of the article did not manage to obtain answers as to a lack of referral to other documents.

\subsection{The number of built scenarios}

The next issue which interested the authors of the article was the number of built scenarios. In keeping with the concept of intuitive logic, the optimal number of developed scenarios for foresight research is two to four. Moreover, such a concept has been promoted by Miles et al. (2007) who at the same time stress that a large number of built scenarios hinders the perception of generated alternatives, can lead to cognitive dissonance and thus become useless for potential decision-makers. Therefore, the authors of the article deemed it legitimate to attempt at identifying the number of scenarios built in the researched Polish regional and sector foresight projects. The outcomes are shown in Figure 5. 


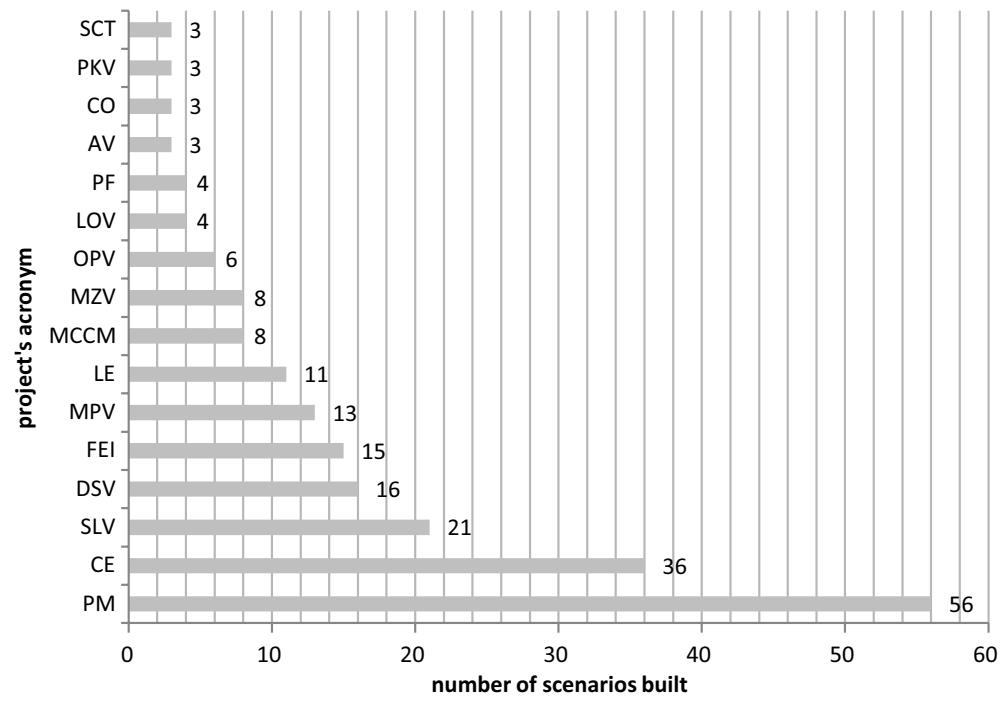

Fig. 5. The number of scenarios built in the researched Polish regional and sector foresight projects Source: own work based on questionnaire results

The data presented in Figure 5 demonstrates that the largest amounts of scenarios were developed in PM and CE, where in total 56 and 36 scenarios, respectively, were created. Many scenarios were also built in SLV, DSV, FEI, MPV, MCCM and MZV, ranging from 21 in SLV to 6 in OPV. The postulate of the intuitive logic school about the number of scenarios was only obeyed by the executors of PF, SCT, AV, CO, LOV and PKV. The authors of the article were unable to obtain information about the number of scenarios built within SWV. High numbers of built scenarios can be explained by applying optimization modelling in LE and CE, while a substantial number of built scenarios in SLV, DSV, FEI, MPV, MCCM and MZV may result from the ineptitude at scenario integration, for example to four alternatives of the researched region development, in keeping with the scenario building postulate of intuitive logic school.

\subsection{Difficulties in scenario building}

Finally, the authors have asked the respondents to name difficulties in scenario building in order to identify any problem areas in applying the method. The difficulties were expressed by nine respondents and were of different types, i.e. some problems concerned the availability of initial statistical data required for scenario building as well as relations between the scenario method and the scope of research areas, while others dealt with the approach to scenario building, outcome popularization or technical aspects. The most frequently encountered difficulty was the lack of statistical data from the scope of the research. The problem was reported by respondents DSV, MPV and CE. Other difficulties included "too broadly defined research areas" that brought about building mutually exclusive scenarios (FEI), working out cohesive scenarios for several research areas (MZV), different approaches to scenario building 
in each panel (PKV) and internalization of foresight results by the authorities and region's decision-makers (OPV). For CO respondents, the crucial difficulty was changeable boundary conditions, i.e. mainly prices of copper and accompanying metals. The PM respondents reported a problem caused by substantial diversity in expert numbers, work quality, the scope of research and timeliness of result delivery.

\section{Conclusions}

The critical analysis of the employment of the scenario method in Polish regional and sector foresight projects presented in this article has allowed for the diagnosis to be established on using the method in the Polish context. The authors have obtained answers to research problems through questionnaire analysis. The expert approach was widely used to scenario building in the analysed projects, although respondents from several projects reported using cross-impact analysis. The analyses of questionnaire data and of detailed reports on project execution methodology led to the identification of four leading scenario building forms, namely optimization modelling, scenario building based on description of key factors, as well as on the results of the Delphi method and the scenario workshop. The data on the structures of experts engaged in the projects and in the scenario method indicates that the achieved consensus on development visions for the researched areas in many cases is not based on a consensus among many social groups. However, despite the lack of explicitness in defining expert structures in the scenario method detected in the majority of researched foresight initiatives, most project executors declared that the choice of experts for the scenario method was intentional. Also, employing the triangulation method for the sake of expert choice raises many doubts; although declared by the majority of the respondents, it stands in opposition to the results of expert structures analysis. The presented analysis has allowed for identification of projects in which unprecedented events were utilized; in some cases, establishing their identification technique, namely brainstorming in accordance with STEEP analysis criteria; and distinguishing rare examples of unprecedented events in the Polish context. However, using unprecedented events in the presented foresight initiatives should be deemed marginal, unstructured, and thus unsatisfying. Moreover, the demonstrated research results imply that in most cases less time is devoted to scenario building than in research of this type worldwide, where the average scenario-building time is six months. Despite the declarations on the expert approach to scenario building, in most cases, project executors also make use of other documents to build scenarios. The results presented in this subsection helped to establish problem areas of applying this method in the Polish context. Among the difficulties, the respondents named, for example, difficult access to statistical data essential for scenario building, research areas defined in an ambiguous way, or problems related to scenario integration. The comments above let the authors diagnose the application of the scenario method in foresight initiatives, and allowed them to identify the critical problems of its usage. 


\section{References}

Aligica, P. D. 2005. Scenarios and the growth of knowledge: notes on the epistemic element in scenario building, Technological Forecasting and Social Change 72(7): 815-824. http://dx.doi.org/10.1016/j.techfore.2005.01.001

Bishop, P.; Hines, A.; Collins, T. 2007. The current state of scenario development: an overview of techniques, Foresight 9(1): 5-25. http://dx.doi.org/10.1108/14636680710727516

Borjeson, L.; Hojer, M.; Dreborg, K-H.; Ekvall, T.; Finnveden, G.; 2006. Scenario types and techniques: towards a user's guide, Futures 38(7): 723-739. http://dx.doi.org/10.1016/j.futures.2005.12.002

Bradfield, R.; Wright, G.; Burt, G.; Cairns, G.; van der Heijden, K. 2005. The origins and evolution of scenario techniques in long range business planning, Futures 37(8): 795-812. http://dx.doi.org/10.1016/j.futures.2005.01.003

Cairns, G.; Ahmed, I.; Mullet, J.; Wright, G. 2013. Scenario method and stakeholder engagement: critical reflections on acclimate change scenarios case study, Technological Forecasting and Social Change 80: 1-10. http://dx.doi.org/10.1016/j.techfore.2012.08.005

Czaplicka-Kolarz, K. (Ed.). 2007. Scenariusze rozwoju technologicznego kompleksu paliwowo-energetycznego dla zapewnienia bezpieczeństwa energetycznego kraju, Cz. 2 [Scenarios of fuel-energy complex technologies development for the country's energy safety guarantee. Part 2]. Katowice, Główny Instytut Górnictwa [Central Mining Institute].

Central Mining Institute 2007. Analiza tematyki projektów typu foresight prowadzonych $w$ Polsce i ocena spójności ich planowanych wyników z zamierzeniami Narodowego Projektu Foresight "Polska 2020" [The analysis of the thematic areas of Polish foresight projects and the assessment of its correspondence to the Polish National Foresight Programme "Poland 2020"], ekspertyza Głównego Instytutu Górnictwa, Katowice.

Decrop, A. 1999. Triangulation in qualitative tourism research, Tourism Management 20: 157-161. http://dx.doi.org/10.1016/S0261-5177(98)00102-2

Drzewiecki, J.; Butra, J.; Kosiór, A. 2008. Scenariusze rozwoju technologicznego przemysłu wydobywczego rud miedzi i surowców towarzyszących w Polsce [Technological development scenarios for copper and accompanying metals mining industry in Poland], Cuprum 1(46): 185-204.

Dubiński, J.; Turek, M. 2008. Sposób tworzenia scenariuszy rozwoju technologicznego przemysłu wydobywczego węgla kamiennego [Scenario building for hard bituminous coal mining technological development], Gospodarka surowcami mineralnymi 24(1/2): 13-30.

Georghiou, L.; Cassingea Harper, J.; Keenan, M.; Miles, I.; Popper, R. 2008. The handbook of technology foresight. Concepts and practice, Prime Series on Research and Innovation Policy, Northampton: Edward Elgar Publishing, Inc.

Gierszewska, G.; Romanowska, M. 2009. Analiza strategiczna przedsiębiorstwa. Warszawa: PWE.

Glińska, U.; Kononiuk, A.; Nazarko, Ł. 2008. Przegląd projektów foresightu branżowego w Polsce [A review of sector foresight projects in Poland], Nauka i Szkolnictwo Wyższe [Science and Higher Education] 2(32): 60-73.

Godet, M.; Roubelat, F. 1996. Creating the future: the use and misuse of scenarios, Long Range Planning 29(2):164-171. http://dx.doi.org/10.1016/0024-6301(96)00004-0

Gudanowska, A. 2011. Mapy wiedzy jako narzędzie lokalizacji zasobów wiedzy w organizacji [Knowledge maps as a localization tool of knowledge resources in organization], Problemy Eksploatacji [Mainetance Problems] 3: 19-31.

Hausner, J. (Ed.). 2008. Foresight technologiczny na rzecz zrównoważonego rozwoju Małopolski [Technological Foresight for Sustainable Development of Małopolska], [online]. Kraków: Małopolska Szkoła Administracji Publicznej at Uniwersytet Ekonomiczny in Kraków, [cited 9 December 2009]. Available from the Internet: http://www.foresight.msap.pl/index.php?page=raports. 
Heijden, K. 1996. Scenarios - the art of strategic conversation. London: Wiley.

Heijden, K.; Bradfield, R.; Burt, G.; Cairns, G.; Wright, G. 2002. The sixth sense: accelerating organizational learning with scenarios. Chichester: Wiley.

Hiltunen, E. 2006. Was it a wild card or just our blindness to gradual change?, Journal of Futures Studies 11(2): 61-74.

Jasiński, A. H. 1999. Metodyka badań rynku [The methodology of market research]. Białystok: Wydawnictwo Uniwersytetu w Białymstoku.

Kleer, J.; Wierzbicki, A. 2009. Narodowy program foresight Polska 2020: Dyskusja założeń scenariuszy [Polish national foresight programme "Poland 2020": The diccusssion of scenarios assumptions], Warszawa: Polska Akademia Nauk. Komitet Prognoz, 'Polska 2000 Plus'.

Kononiuk, A. 2009. Sposoby identyfikacji zdarzeń bezprecedensowych jako remedium na uniknięcie bądź łagodzenie skutków potencjalnego kryzysu [Ways of identifying unprecedented events as a remedy for avoiding or moderating of effects of potential crisis], Prace i Materialy Wydziału Zarządzania Uniwersytetu Gdańskiego [Works and Materials of the Faculty of Management at the University of Gdansk] 3(2): 527-537.

Kononiuk, A. 2010. Metoda scenariuszowa w antycypowaniu przyszłości (na przykładzie Narodowego Programu Foresight "Polska 2020"), Warszawa [Scenario analysis in future anticipation (in the light of the "Polish National Foresight Programme 2020"], unpublished PhD thesis, Warsaw University, Warsaw.

Kononiuk, A. 2013. Foresight jako nurt badawczy w naukach o zarządzaniu [Foresight as a research trend in management sciences], Wspótczesne Zarządzanie, forthcoming.

Kononiuk, A.; Magruk, A.; Nazarko, L. 2009. The concept of support group in the Polish National Foresight Programme "Poland 2020", in Matwiejczuk, W. (Ed.). Zarządzanie organizacją w nowej rzeczywistości gospodarczej: wybrane problem. Diffin, Warszawa.

Kowalewska, A.; Głuszczyński, I. 2009. Rola metody delfickiej w Narodowym Programie Foresight "Polska 2020" [The role of Delphi method in the Polish National Foresight Program "Poland 2020"]. Warszawa: Pentor Research International.

Lindgren, M.; Banhold, H. 2003. Scenario planning, the link between future and strategy. New York: Palgrave Macmillan.

Magruk, A. 2009. 'Weak signals' w procesie zarządzania kryzysowego [Weak signals in the process of crisis management], Prace i Materiały Wydziału Zarządzania Uniwersytetu Gdańskiego 3(2): 517-526.

Magruk, A. 2011. Innovative classification of technology foresight methods, Technological and Economic Development of Economy 17(4): 700-715. http://dx.doi.org/10.3846/20294913.2011.649912

Miles, I.; Ravetz, J.; Ringland, G. 2007. A specialised course on scenario building, UNIDO, 5-8 November, Prague.

Ministerstwo Nauki i Szkolnictwa Wyższego [Ministry of Science and Higher Education]. 2009. Wyniki Narodowego Programu Foresight "Polska 2020" [The results of the Polish National Foresight Programme „Poland 2020”]. Warszawa.

Nazarko, J.; Ejdys, J. (Eds.). 2011. Metodologia i procedury badawcze w projekcie Foresight Technologiczny NT for Podlaskie2020: Regionalna strategia rozwoju nanotechnologii [Methodology and Research Procedures in Technology foresight “NT FOR Podlaskie 2020”. Regional strategy of nanotechnology development]. Oficyna Wydawnicza Politechniki Białostockiej, Bialystok.

Nazarko, J.; Wnorowski, H.; Kononiuk, A. (Eds.). 2011. Analiza strukturalna czynników rozwoju nanotechnologii w województwie podlaskim [Structural analysis of nanotechnology development factors in Podlaskie Voivodship]. Bialystok: Oficyna Wydawnicza Politechniki Białostockiej.

Nazarko, J. (Ed.). 2012. Badanie ewaluacyjne realizowanych $w$ Polsce projektów foresight [Evaluation research of the Polish foresight projects]. Warszawa: Ministerstwo Nauki i Szkolnictwa Wyższego. 
Nazarko, J; Glinska, U.; Kononiuk, A; Nazarko, Ł. 2013. Sectoral foresight in Poland: thematic and methodological analysis, International Journal of Foresight and Innovation Policy 9(1): 19-38. http://dx.doi.org/10.1504/IJFIP.2013.051759

Notten, P. van; Rotmans, J.; Asselt, M. B. A. van; Rothman, D. S. 2003. An updated scenario typology, Futures 35: 423-443. http://dx.doi.org/10.1016/S0016-3287(02)00090-3

O'Keefe, M.; Wright, G. 2010. Non-receptive organizational contexts and scenario planning interventions: a demonstration of inertia in the strategic decision-making of a CEO, despite strong pressure for a change, Futures 42(1): 26-41. http://dx.doi.org/10.1016/j.futures.2009.08.004

Perechuda, K.; Sobińska, M. 2008. Scenariusze, dialogi i procesy zarządzania wiedza [Scenarios, dialogue and processes of knowledge management], Warszawa: Difin.

Ringland, G. 1998. Scenario Planning: Managing for the Future. Chichester: Wiley.

Rogut, A.; Piasecki, B. 2008. Regionalna Strategia Innowacji dla województwa Łódzkiego [Regional Innovation Strategy for the Łódzkie Voivodship], RSI LORIS PLUS, Łódź: Społeczna Wyższa Szkoła Przedsiębiorczości i Zarządzania w Łodzi.

Rogut, A.; Piasecki, B. 2011. Podręcznik ewaluatora projektów foresight [The handbook of foresight projects' evaluator]. Warszawa: Ministerstwo Nauki i Szkolnictwa Wyższego.

Sacio-Szymańska, A.; Poteralska, B.; Mazurkiewicz, A. 2010. Zastosowanie metody roadmappingu technologicznego w projektach foresight [The application of road mapping method in foresight projects], Zarządzanie i marketing. Zeszyty Naukowe Politechniki Rzeszowskiej 17(3): 335-346.

Saritas, O.; Nugroho, Y. 2012. Mapping issues and envisaging futures: an evolutionary scenario approach, Technological Forecasting and Social Change 79(3): 509-529. http://dx.doi.org/10.1016/j.techfore.2011.09.005

Sarpong, D. 2011. Towards a methodological approach: theorising scenario thinking as a social practice, Foresight 13(2): 4-17. http://dx.doi.org/10.1108/14636681111126210

Stake, R. E. 2009. Jakościowe studium przypadku [Qualitative case study] in Denzin, N. K.; Lincoln, Y. S. Metody badań jakościowych, PWN, Warszawa, vol. 1, 623-654.

Stewart, C. C. 2008. Integral scenarios: reframing theory, building from practice, Futures 40: 160-172. http://dx.doi.org/10.1016/j.futures.2007.11.013

Szewczyk, R. (Ed.). 2008. Foresight województwa mazowieckiego. Krzyżowa analiza wplywów, scenariusze rozwoju, priorytetowe technologie [Foresight for the Mazowieckie Voivodship. A cross analysis of influences, development scenarios, priority Technologies], [online], [cited 12 May 2010] Available from Internet: www. formazovia.pl.

Tsoukas, H.; Shepherd, J. 2004. Managing the future, foresight in the knowledge economy. Bodmin: Blackwell Publishing.

Van der Heidjen, K.; Schutte, P. 2000, Look before you leap: key questions for designing scenario applications, Scenario and Strategy Planning 1(6): 20-24.

Vliet, M. van; Kok, K.; Veldkamp, A.; Arkki, S. 2012. Structure in creativity: an exploratory study to analyse the effects of structuring tools on scenario workshop results, Futures 44(8): 746-760. http://dx.doi.org/10.1016/j.futures.2012.05.002

Wójcicki, J. M.; Ladyzynski, P. 2008. System monitorowania i scenariusze rozwoju technologii medycznych w Polsce [Monitoring System and Scenarios of Medical Technologies Development in Poland].Warszawa.

Zavadskas, E. K.; Turskis, Z. 2010. A new additive ratio assessment (ARAS) method in multicriteria decision-making, Technological and Economic Development of Economy 16(2): 159-172. http://dx.doi.org/10.3846/tede.2010.10

Zurek, M. B.; Henrichs, T. 2007. Linking scenarios across geographical scales in international environmental assessments, Technological Forecasting and Social Change 74 (8): 1282-1295.

http://dx.doi.org/10.1016/j.techfore.2006.11.005 
Joanicjusz NAZARKO is a Professor at the Bialystok University of Technology in Poland. He serves as Dean of the Faculty of Management and Head of the Department of Business Informatics and Logistics. He has published over 200 publications and a number of expert assessments, projects and technical and economic elaborations. He was a member of the Steering Committee of the National Foresight Program "Poland 2020". He has served as an expert of the EU 7th Framework Program. He is an IEEE senior member. He is a recognised expert in the fields of forecasting, simulation, foresight and benchmarking.

Anna KONONIUK is a Researcher in the Chair of Business Informatics and Logistics at the Management Faculty of Bialystok University of Technology, Poland. She holds a PhD in Management from the Warsaw University. She was one of the initiators of the Support Group in the National Foresight Program "Poland 2020". Currently, she is involved as a member of key research teams in foresight projects of regional, trade and national type. Her scientific research interests are forecasting, time series analysis, social network analysis and foresight methods with an emphasis on scenario analysis. 